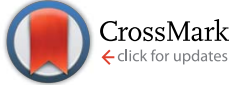

Cite this: RSC Adv., 2015, 5, 28219
Received 4th March 2015

Accepted 16th March 2015

DOI: $10.1039 / \mathrm{c} 5 \mathrm{ra03871e}$

www.rsc.org/advances

\section{In vitro and in vivo studies of temozolomide loading in zeolite structures as drug delivery systems for glioblastoma}

\author{
Olga Martinho, ${ }^{a b c}$ Natália Vilaça, ${ }^{d}$ Paulo J. G. Castro, ${ }^{d}$ Ricardo Amorim, ${ }^{\text {ab }}$ \\ António M. Fonseca, ${ }^{d}$ Fátima Baltazar, ${ }^{\text {ab }}$ Rui M. Reis ${ }^{\star a b c}$ and Isabel C. Neves*d
}

\begin{abstract}
Zeolites Y (faujasite) and MOR (mordonite) were used as hosts for temozolomide (TMZ), a current goodstandard chemotherapeutic agent used in the treatment of glioblastoma brain tumors. TMZ was loaded into zeolites by liquid-phase adsorption at controlled $\mathrm{pH}$. FTIR, ${ }^{1} \mathrm{H}$ NMR, MS, SEM, UV/vis and chemical analysis demonstrated the successful loading of TMZ into zeolite hosts. The hydrolysis of TMZ in MTIC (TMZ metabolite) after the preparation of drug delivery systems (DDS) was observed in simulated body fluid. The effect of zeolites and DDS were evaluated on the viability of glioblastoma cell lines. Unloaded $Y$ zeolite presented toxicity to cancer cells in contrast to MOR. In accordance, the best results in potentiation of the TMZ effect was obtained with MOR. We found that mordonite loaded with 0.026 mmol of TMZ was able to decrease the half maximal inhibitory concentrations $\left(\mathrm{IC}_{50}\right)$ at least 3-fold in comparison to free temozolomide both in vitro and in vivo.
\end{abstract}

\section{Introduction}

Glioblastomas (World Health Organization, malignancy grade 4), are the most common and aggressive primary central nervous system tumors. ${ }^{1,2}$ In the last decades we have witnessed significant advances in the treatment of glioblastomas patients, the current gold-standard being neurosurgery, followed by radiotherapy followed by concomitant radio and temozolomide-based chemotherapy. ${ }^{2,3}$ Despite these advances, the median reported survival is of approximately 15 months $^{3-5}$ and only around $5 \%$ of patients are alive 5 years following diagnosis. ${ }^{2,3}$ Therefore, more effective therapeutic options are urgently needed.

Temozolomide (TMZ) is a cytotoxic prodrug that, when hydrolyzed, inhibits DNA replication by methylating nucleotide bases. $^{6,7}$ In preclinical testing, TMZ has shown a broad spectrum of antineoplastic activity. ${ }^{7,8}$ Predictable bioavailability and minimal toxicity make TMZ a candidate for a wide range of clinical testing to evaluate the potential of combination treatments in different tumor types. ${ }^{6,9}$ TMZ has lately been approved by USA Food and Drug Administration (FDA) for the treatment of adult patients with refractory anaplastic astrocytoma and, in the Europe for treatment of glioblastoma showing progression

\footnotetext{
${ }^{a}$ Life and Health Sciences Research Institute (ICVS), School of Health Sciences, University of Minho, Campus Gualtar, Braga, Portugal

${ }^{b} I C V S / 3 B$ 's - PT Government Associate Laboratory, Braga/Guimarães, Portugal ${ }^{c}$ Molecular Oncology Research Center, Barretos Cancer Hospital, Barretos, São Paulo, Brazil. E-mail: rreis@ecsaude.uminho.pt

${ }^{d}$ Centre of Chemistry, Chemistry Department, University of Minho, Campus de Gualtar,4710-057 Braga, Portugal.E-mail: ineves@quimica.uminho.pt
}

or recurrence after standard therapy. ${ }^{4,5}$ Currently, concomitant radiotherapy and TMZ [daily TMZ $(75 \mathrm{mg}$ per square meter of body-surface area per day, 7 days per week from the first to the last day of radiotherapy), followed by six cycles of adjuvant TMZ (150 to $200 \mathrm{mg}$ per square meter for 5 days during each 28 day cycle)] regimen is the standard of care for patients diagnosed with malignant gliomas (anaplastic astrocytomas and glioblastomas). ${ }^{4,5}$ Several groups, including ours, reported that the genetic features of tumors, in particular the status of MGMT and PI3KCA/HOX gene signature, can influence the response of GBM patients to TMZ treatment. ${ }^{\mathbf{1 0 - 1 4}}$

TMZ is a bicyclic heterocyclic compound, chemically classed as an imidazotetrazinone. The defining characteristic of this class of compound is an imidazole ring that is fused with a tetrazinone ring system that contains three adjacently bonded nitrogen atoms. ${ }^{7}$ TMZ is a small lipophilic molecule that can be absorbed in the digestive tract, does not require hepatic metabolism for activation, and it can cross the blood-brain barrier and enters the cerebrospinal fluid..$^{7,8}$ It is stable at the acidic $\mathrm{pH}$ of the stomach, but once it is in contact with the slightly basic $\mathrm{pH}$ of the blood, TMZ suffers hydrolysis to the active metabolite 3-methyl-(triazen-1-yl)imidazole-4-carboxamide (MTIC), which rapidly breaks down to form the highly reactive methyldiazonium ion and to an inactive carboxylic acid derivative, 5-aminoimidazole-4-carboxamide (AIC) (Fig. 1).,15,16

Therefore, TMZ is spontaneously converted to MTIC, which is the active structure with anti-neoplastic action. ${ }^{7}$ The drug delivery systems (DDS) could be to circumvent the conversion of TMZ and keeps the stability of the inactive molecular configuration until the targeting within the glioblastomas. There are 
<smiles>Cn1nnc2c(C(N)=O)ncn2c1=O</smiles><smiles>CN/N=N/c1[nH]cnc1C(N)=O</smiles>

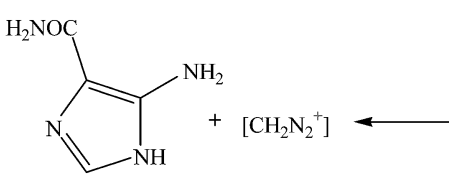

AIC

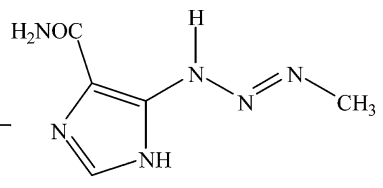

MTIC
Fig. 1 Pathway of decomposition of temozolomide..$^{15,16}$

only a few studies with TMZ prepared as DDS. ${ }^{17-21}$ To the best of our knowledge, there are no studies using zeolite structures as a host to entrap the chemotherapeutic agent as TMZ used in the treatment of glioblastoma brain tumors. Recently the zeolites show promise host for keep the anticancer drugs without molecular modifications..$^{22-26}$

Zeolite structures are very interesting porous materials, due to their structural properties and stability in biological environments..$^{22,23,26}$ Zeolites are acid solid inorganic crystalline materials comprised of silicon, aluminum and oxygen in the threedimensional structure. The building blocks become arranged in a periodic way to form channels and cages on a nano- and subnanometer scale of strictly regular dimensions, named micropores. ${ }^{27}$ The pores of zeolites are open to the exterior and to the surrounding medium, thus allowing diffusion of molecules from the exterior to the interior of the zeolite particle. ${ }^{27}$

In our group we have already reported the preparation of DDS based on zeolite structures with experimental anticancer drugs, $\alpha$-cyano-4-hydroxycinnamic acid (CHC) and 5-fluorouracil (5-FU), and demonstrated its in vitro efficacy against colorectal carcinoma cells. ${ }^{24,25,28}$ In these studies, we have shown that the zeolite structures are not toxic to HCT-15 (ref. 24 and 25) and RKO cells ${ }^{28}$ and the drug potentiation was dependent on the zeolite structure. The study performed by Fenoglio et $a l .{ }^{29}$ shows that the zeolites with spheroid form as FAU, ${ }^{24,25,28}$ LTA $^{24,25}$ and LTL, ${ }^{24,25,28}$ exhibited low levels of cytotoxicity even at high concentrations in the cell medium. Furthermore, toxicity studies showed that the internal surface of the zeolites does not have influence over the toxicity because the internal surface does not interact with the biological system. ${ }^{30}$

In the present study, the chemotherapeutic agent TMZ was loaded by diffusion in liquid phase at controlled $\mathrm{pH}$ in the void space of two zeolite structures: faujasite (Y) and mordonite (MOR). These microporous aluminosilicate frameworks, so called large pore, are different. Y zeolite is based on sodalite cages linked together, forming a large central cavity or supercage, with a diameter of $12.5 \AA$ communicated through $7.4 \AA$ pores. In contrast mordenite zeolite does not present supercages; instead, it presents bidimensional channels with 12- membered ring apertures with a diameter of $7.0 \times 6.5 \AA$ connected by short alternating 8-ring channels $(\approx 3 \AA) \cdot{ }^{31-35}$

Different characterization methods, scanning electron microscopy (SEM), Fourier-transform infrared spectroscopy (FTIR), ultraviolet visible spectroscopy (UV/vis), nuclear magnetic resonance of proton $\left({ }^{1} \mathrm{H}\right.$ NMR) mass spectrometry (MS) and chemical analysis demonstrated the successful loading of TMZ into both zeolite hosts. The conversion of TMZ into MTIC after the preparation of DDS was screening in simulated body fluid. The effect of zeolites and DDS was evaluated on the viability of glioblastoma cells in comparison with zeolites and temozolomide alone.

\section{Experimental}

\section{Preparation of DDS}

Loading of temozolomide (TMZ with $99 \%$ of purity was obtained from Sigma-Aldrich (Portugal)) in zeolites was based on a previously established procedure. ${ }^{24,25,28}$ Briefly, before TMZ loading, the zeolites, NaY (CBV100) and NaMOR (CBV10A) powders, obtained from Zeolyst International (USA), were dehydrated at $120{ }^{\circ} \mathrm{C}$ overnight in order to remove the water from the pores. TMZ loading into the zeolites was achieved by mixing $100 \mathrm{mg}$ of each zeolite with a solution of TMZ $(2.9 \mathrm{mg}, 0.015 \mathrm{mmol})$ in methanol (Merck, $15 \mathrm{~mL}$ ) as a solvent and were stirred (300 rpm) for $48 \mathrm{~h}$ at room temperature. The mixture was decanted for reducing the solvent volume. After that, the resulting DDS were dried in an oven at $60{ }^{\circ} \mathrm{C}$ for $12 \mathrm{~h}$ and stored in a desiccator. This temperature is enough to evaporate the methanol solvent. Other sample with different TMZ concentration, $0.026 \mathrm{mmol}$ TMZ (5 mg) was prepared in MOR zeolite under the same experimental conditions. The $\mathrm{pH}$ of the mixture was monitored during at beginning and the end of the DDS preparation. Hereinafter, the obtained DDS will be referred to as $\mathrm{TMZ}_{n}$-zeolite, where zeolite represents the structure of the zeolite used and $n$ represents the amount of TMZ in DDS (mmol).

The stability of TMZ after the release from DDS was evaluated. The simulated body fluid was made using known amounts of a buffer solution of sodium monobasic phosphate and sodium dibasic phosphate. Known amounts of the DDS were mixed $(10 \mathrm{mg})$ in $50 \mathrm{~mL}$ of simulated body fluid in order to simulate body fluid at $\mathrm{pH} 7.4$ and $37{ }^{\circ} \mathrm{C}$. The samples were stirred at ca. $60 \mathrm{rpm}$ during $48 \mathrm{~h}$. After that, the suspensions were centrifuged at $6000 \mathrm{rpm}$ during $10 \mathrm{~min}$ in order to ensure that all TMZ issue for the solution. The supernatants were analyzed by UV/vis, ${ }^{1} \mathrm{H}$ RMN and MS.

\section{Characterization methods}

Elemental analysis for carbon, nitrogen, and hydrogen were carried out on LECO CHNS-932 equipment. Samples were combusted at $1000{ }^{\circ} \mathrm{C}$ for $3 \mathrm{~min}$ with helium used as the purge gas. Scanning electron micrographs (SEM) were collected on a LEICA Cambridge S360 Scanning Microscope equipped with an EDX system. In order to avoid surface charging, samples were coated with gold in vacuum prior to analysis, by using a Fisons Instruments SC502 sputter coater. Room temperature Fourier 
transform infrared (FTIR) spectra of the samples in $\mathrm{KBr}$ pellets ( $2 \mathrm{mg}$ of sample was mixed in a mortar with $200 \mathrm{mg}$ of $\mathrm{KBr}$ ) were measured using a Bomem MB104 spectrometer in the range $4000-500 \mathrm{~cm}^{-1}$ by averaging 20 scans at a maximum resolution of $4 \mathrm{~cm}^{-1}$. Mass spectrometry analyses were performed on an Analytical Fison Instruments Auto Spec $V G$ at the University of Santiago de Compostela, Spain. ${ }^{1} \mathrm{H}$ NMR spectra were obtained on a Varian Unity Plus Spectrometer at an operating frequency of $300 \mathrm{MHz}$ using the solvent peak as internal reference at $25^{\circ} \mathrm{C}$, chemical shifts of protons being given in ppm using $\delta_{\mathrm{H}} \mathrm{Me}_{4} \mathrm{Si}=$ $0 \mathrm{ppm}$ as reference. The electronic UV/vis absorption spectra of drug and the release studies were collected in the range 600-200 $\mathrm{nm}$ in a Shimadzu UV/2501PC spectrophotometer using quartz cells at room temperature.

\section{Cell culture conditions and cell viability assays}

For the cellular viability assays, the DDS were prepared as stock suspensions of $1 \mathrm{mg} \mathrm{mL} \mathrm{mL}^{-1}$ in culture medium without fetal bovine serum (FBS). The intermediate dilutions were prepared from this stock also in DMEM without FBS, and the suspensions were submitted to ultrasonic dispersion for $2 \mathrm{~min}$ prior to use. In the conditions, where TMZ was used alone as stock solution, was prepared in dimethyl sulfoxide (DMSO) and stored at $-20{ }^{\circ} \mathrm{C}$. The drug was subsequently prepared as intermediate dilutions in DMSO to obtain an equal quantity of DMSO (1\% final concentration) in each of the conditions studied, diluted in $0 \%$ FBS culture medium.

Human glioblastoma cells, U251, kindly provided by Prof. Joseph Costello, (California University Neurosurgery Department, St. Francisco, USA), and SNB-19, obtained from DSMZ (German Collection of Microorganisms and Cell Cultures) were maintained in DMEM medium (Dulbecco's Modified Eagle Medium, Gibco), supplemented with 10\% (v/v) FBS (Gibco, Invitrogen, USA) and $1 \%(\mathrm{v} / \mathrm{v})$ penicillin-streptomycin solution $(\mathrm{P} / \mathrm{S})$ (Invitrogen, USA) and incubated at $37{ }^{\circ} \mathrm{C}$ in a $5 \% \mathrm{CO}_{2}$ humidified atmosphere. ${ }^{36}$

To determine the cytotoxic effect and the concentration at which $50 \%$ of the cell growth is inhibited ( $\mathrm{IC}_{50}$ concentration) by the treatments, the cells were plated into 96-well plates at a density of $2 \times 10^{3}$ cells per well or in 12 -well plates at a density of $5 \times 10^{4}$ and allowed to adhere overnight in DMEM with $10 \%$ of FBS as previously described. ${ }^{34}$ Subsequently, the cells were treated with increasing concentrations of the DDS or TMZ alone in DMEM without FBS. After $72 \mathrm{~h}$, cell viability was quantified using the MTS assay (Cell Titer96 Aqueous cell proliferation assay, Promega) in the 96-well plates and by viable cell counting with trypan blue staining in 12-well plates. The results were expressed as mean $\pm \mathrm{SD}$ viable cells relatively to the conditions without TMZ or without of DDS (considered as 100\% viability). The $\mathrm{IC}_{50}$ concentration was calculated by nonlinear regression analysis.

Single comparisons between the different conditions studied were done using Student's $t$ test, and differences between groups were tested using two-way analysis of variance (ANOVA). Statistical analysis of the results was done using Graph Pad Prism version 5 . The level of significance in all the statistical analysis was set at $p<0.05$. All assays were performed in triplicate at least three times.

\section{In vivo chick chorioallantoic membrane (CAM) assay}

To assess the effect of DDS on tumor proliferation and angiogenesis in vivo we used the CAM assay, as previously described..$^{36,37}$ Fertilized chicken eggs were incubated at $37{ }^{\circ} \mathrm{C}$ and $70 \%$ humidity, and on day 3 of development, a window was made into the shell and the eggs were returned to the incubator. On day $8,2 \times 10^{3}$ cells were ressuspended in $20 \mu \mathrm{L}$ of Matrigel (BD Biosciences) and placed over the CAM. On day 12, the formed tumors were photographed in ovo using a stereomicroscope (Olympus S2 $\times 16$ ). Next, $20 \mu \mathrm{L}$ of FBS-free culture medium containing the DDS or DMEM alone for control, were injected under the tumors. At day 17 (5 days of incubation with the drug), the tumors were again photographed in ovo. The chicken embryos were sacrificed at $-80^{\circ} \mathrm{C}$ for $10 \mathrm{~min}$, and the tumors or CAM alone were fixed with paraformaldehyde at $4 \%$ and photographed ex ovo. The perimeter of the tumors was measured using Cell B software (Olympus) in ovo at day 12 and 17. The results were expressed as mean perimeter \pm SD of tumor growth for each group.

\section{Results and discussion}

\section{Loading and characterization of DDS}

In the present study, the DDS were prepared with two different zeolitic structures by adsorption of TMZ in liquid phase within the zeolite frameworks by previously established procedure, ${ }^{24,25,28}$ with controlled $\mathrm{pH}$ during the preparation in order to avoid TMZ hydrolysis. This chemotherapeutic agent is stable at acidic $\mathrm{pH}$ values and labile above $\mathrm{pH} 7$, exactly the conversation obtained with the ring-opened species MTIC, which is unstable below pH 7 but more stable at alkaline $\mathrm{pH}$ values. ${ }^{38}$ Besides, the characteristic molecular dimensions of the TMZ molecule are $4.64 \AA$ (C6 to N2) × $8.43 \AA$ (C8 to C4) × 8.41 $\AA$ (C8 to $\mathrm{CH}_{3}$ group), which can easily diffuse into both micropores of the zeolites, NaY and NaMOR.

$\mathrm{NaY}$ zeolite presented lower $\mathrm{Si} / \mathrm{Al}$ ratio $(\mathrm{Si} / \mathrm{Al}=2.83)$ and exhibit large specific surfaces area, $787 \mathrm{~m}^{2} \mathrm{~g}^{-1}$, than NaMOR which have $\mathrm{Si} / \mathrm{Al}$ ratio of 6.50 and surface area of $425 \mathrm{~m}^{2} \mathrm{~g}^{-1} .^{31}$ Lower $\mathrm{Si} / \mathrm{Al}$ ratios indicate more aluminum in the structure that enhances higher acidity for the support. NaY zeolite is more acidic than NaMOR zeolite. However, NaY and NaMOR present $3 \mathrm{D}$ and $1 \mathrm{D}$ structure, respectively, which suggest more steric restrictions for TMZ release from faujasite structure.

The morphology of the zeolites after TMZ loading was obtained by SEM analysis. The preparation of the DDS does not modify the morphology of the zeolite structures. Fig. 2 shows the digital image analysis of parent zeolites and $\mathrm{TMZ}_{0.026}$ zeolites.

The SEM micrographs of parent zeolites and the DDS indicate that no changes occur in the morphology and structure upon introduction of the drug. Analysis of SEM micrographs shows that NaY and DDS (Fig. 2a and b) have similar 


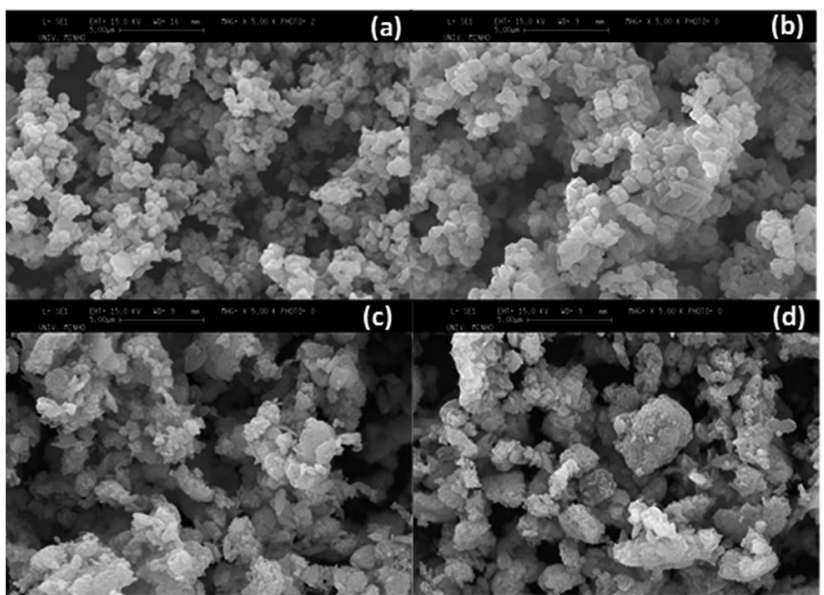

Fig. 2 SEM micrographs of (a) NaY, (b) $\mathrm{TMZ}_{0.026}-\mathrm{Y}$, (c) NaMOR and (d) $\mathrm{TMZ} \mathrm{Z}_{0.026}-\mathrm{MOR}$

morphology, typical of the faujasite structure, with regular small particles.

In contrast, the starting MOR (Fig. 2c) and its DDS (Fig. 2d) show different types of particles, as determined by digital image analysis. In both DDS, the incidence of the temozolomide was clearly confirmed by energy-dispersive X-ray analysis, which detected the presence of nitrogen from the TMZ molecule on the spotted surface.
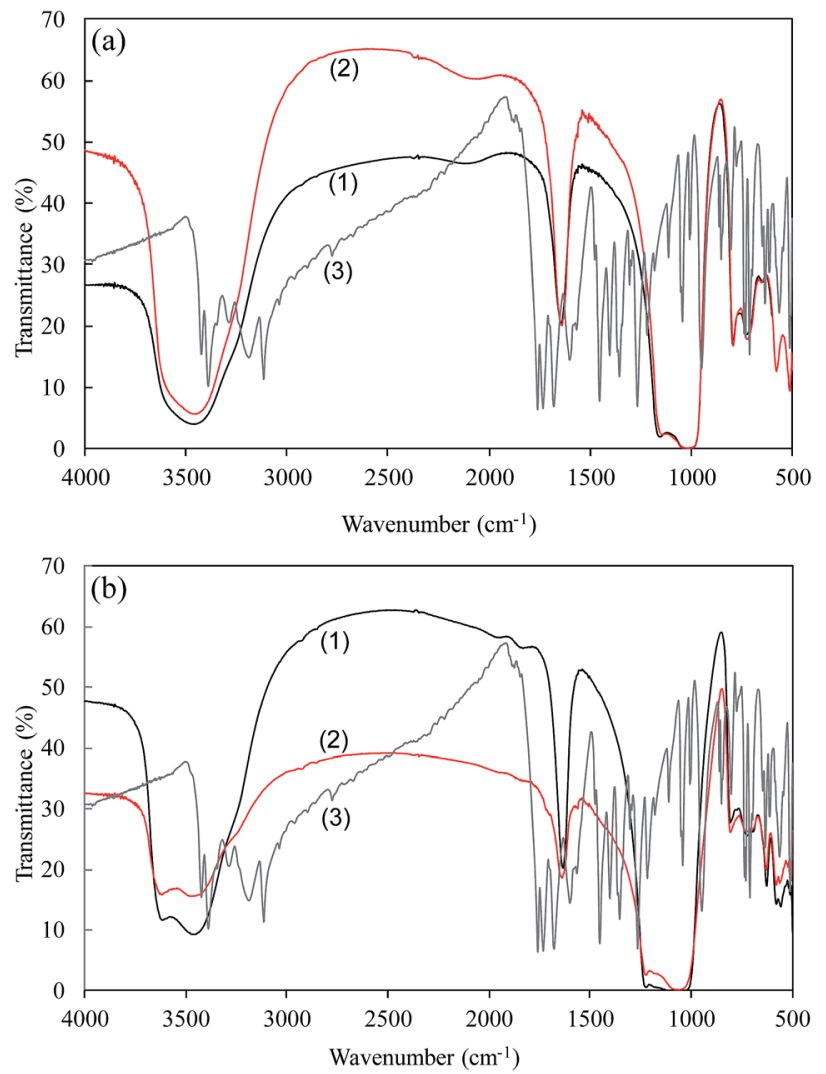

Fig. 3 FTIR spectra of (a) NaY and (b) NaMOR, representing the (1) zeolite alone, (2) $T M Z_{0.015}$-zeolite and (3) $T M Z$ alone.
Fourier transformed infrared spectroscopy (FTIR) provides information about the integrity of the hosts and the presence of the drug. The FTIR spectra of TMZ, DDS and parent zeolites are shown in parts (a) NaY and (b) NaMOR of Fig. 3.

The TMZ spectrum shows the characteristic vibrational modes of the drug molecule. ${ }^{39}$ The bands at 1760, 1735 and $1680 \mathrm{~cm}^{-1}$ are attributed to the carbonyl groups $(\mathrm{C}=\mathrm{O})$ stretching. The band at $1600 \mathrm{~cm}^{-1}$ is attributed to $\nu(\mathrm{N}-\mathrm{H})$ deformation. The bands at $1450 \mathrm{~cm}^{-1}$ are attributed to $\mathrm{C}-\mathrm{N}$ stretching and the $\mathrm{C}-\mathrm{C}$ stretching vibration band is observed at $1357 \mathrm{~cm}^{-1}$. The bands at 3387,3287 and $3228 \mathrm{~cm}^{-1}$ are attributed to $\nu(\mathrm{N}-\mathrm{H})$ stretching. For the prepared DDS, the FTIR spectra are dominated by the strong bands assigned to the vibrational modes arising from the zeolite structures. The presence of physisorbed water is detected by the $\nu(\mathrm{O}-\mathrm{H})$ stretching vibration at $3500 \mathrm{~cm}^{-1}$ and the $\nu(\mathrm{O}-\mathrm{H})$ deformation band at $1650 \mathrm{~cm}^{-1}$. In the former band for NaMOR, there is a shoulder band at around $3640 \mathrm{~cm}^{-1}$ assigned to $\mathrm{OH}$ in Si-(OH)Al groups in the framework, which corresponds to Brønsted acidity. ${ }^{32-34,40}$ The large and broad peak at 1080 and $1240 \mathrm{~cm}^{-1}$ is due to asymmetric stretching vibration from $\mathrm{O}-\mathrm{Si}-\mathrm{O}$, while framework vibrations appear in the region $650-500 \mathrm{~cm}^{-1} .{ }^{28-32} \mathrm{In}$ DDS, the principal zeolite vibrational bands no shift or broadening upon inclusion of the drug, indicating that the zeolite frameworks remain unchanged. Residual methanol was not observed in both DDS, endorsing that the solvent was completely removed during the preparation.

However, the characteristic TMZ FTIR vibrational bands in the TMZ-zeolite spectra are weak, and due to overlap with the strong bands arising from the zeolite frameworks, it is not possible to draw any further conclusions from these data.

The integrity of the TMZ in zeolites was further confirmed by the analytical data of carbon and nitrogen content obtained by elemental analysis. The theoretically $\mathrm{C} / \mathrm{N}$ ratio for TMZ is 0.86 (37.1\% to $\mathrm{C}$ and $43.3 \%$ to $\mathrm{N}$ ). All DDS based in different zeolites present similar $\mathrm{C} / \mathrm{N}$ ratio with 0.89 for $\mathrm{TMZ}-\mathrm{Y}_{0.015}(0.63 \%$ to $\mathrm{C}$ and $0.71 \%$ to $\mathrm{N}$ ), with 0.87 for TMZ-MOR $\mathrm{MO}_{0.015}(0.85 \%$ to $\mathrm{C}$ and $0.98 \%$ to $\mathrm{N}$ ) and with 0.89 for TMZ-MOR $\mathrm{M}_{0.026}(0.61 \%$ to $\mathrm{C}$ and $0.69 \%$ to $\mathrm{N}$ ) indicating only the presence of the molecular drug structure in the zeolite. These results suggest that the hydrolysis of TMZ molecule does not occur inside the zeolites because in the TMZ modification the ring of the molecule is cleaved and the carbon dioxide is lost (Fig. 1) which implies in this case a lower $\mathrm{C} / \mathrm{N}$ ratio.

In order to verify the hydrolysis of TMZ molecule after the preparation of DDS, the supernatants were analyzed by UV/vis, ${ }^{1} \mathrm{H}$ RMN and MS. In the UV/vis spectrum, the presence of residual drug was evidenced by the appearance of an intense band at $\lambda_{\max }=290 \mathrm{~nm}$ in the different position of TMZ in methanol $\left(\lambda_{\max }=326 \mathrm{~nm}\right) \cdot{ }^{38,39}$ The ${ }^{1} \mathrm{H}$ NMR spectra of the samples were recorded at $300 \mathrm{MHz}$ in $\mathrm{CDCl}_{3}$. The chemical shifts of protons observed for TMZ are $\delta 8.5(\mathrm{~s}, \mathrm{CH}), 7.5\left(\mathrm{~d}, \mathrm{NH}_{2}\right)$ and $3.9\left(\mathrm{~s}, \mathrm{CH}_{3}\right) .^{38}$ However, for the residual solution, the chemical shifts of protons are $\delta 8.0(\mathrm{~s}, \mathrm{CH}), 7.2\left(\mathrm{~d}, \mathrm{NH}_{2}\right), 5.2(\mathrm{sh}$, $\mathrm{NH}), 4.3(\mathrm{sh}, \mathrm{NH})$ and $1.5\left(\mathrm{~s}, \mathrm{CH}_{3}\right)$ and are different from the chemical shifts of the TMZ molecule. The mass spectrum show $m / z 168.07539\left[\mathrm{M}^{+}\right.$calcd 168.07541 for $\left.\mathrm{C}_{5} \mathrm{H}_{8} \mathrm{ON}_{6}\right]$ attributed to 


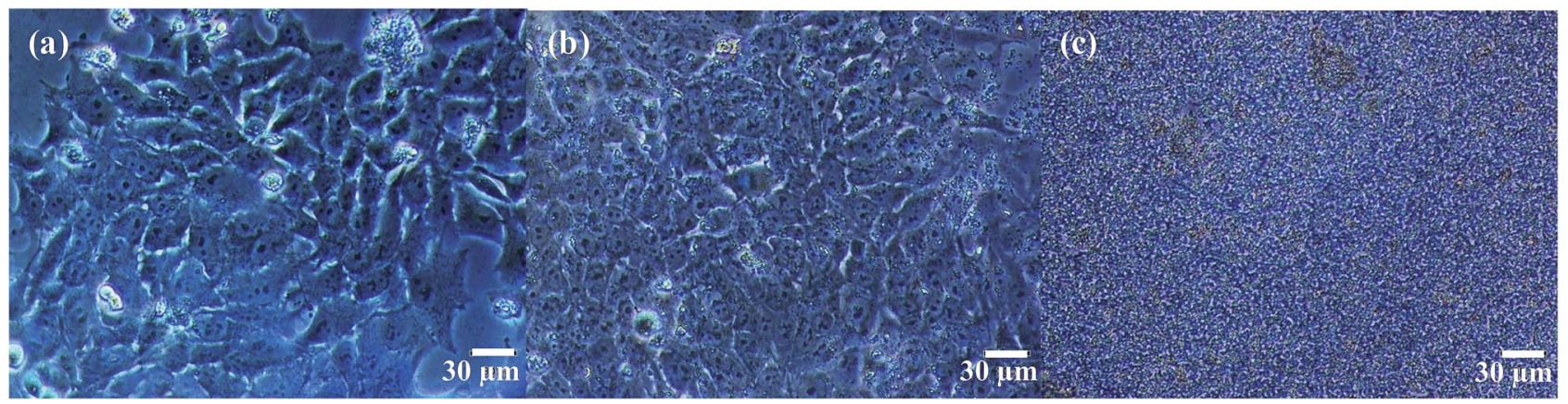

Fig. 4 Optical microscopy images showing U251 cells with (a) $0 \mathrm{mg} \mathrm{mL}^{-1}$ of DDS, (b) $0.05 \mathrm{mg} \mathrm{mL}^{-1}$ of TMZ $0.026-\mathrm{MOR}$ and (c) $0.75 \mathrm{mg} \mathrm{mL}^{-1}$ of $\mathrm{TMZ}_{0.026}-\mathrm{MOR}$ with $100 \times$ magnification.

Table 1 Final assay concentrations of TMZ $(\mu M)$ in the different DDS

\begin{tabular}{|c|c|c|c|c|c|c|c|c|}
\hline $\operatorname{DDS}\left(\mathrm{mg} \mathrm{mL}^{-1}\right)$ & 1.000 & 0.025 & 0.050 & 0.100 & 0.200 & 0.300 & 0.500 & 0.750 \\
\hline $\mathrm{TMZ}_{0.015}-\mathrm{Y}(\mu \mathrm{M} \mathrm{TMZ})$ & 145.0 & 3.63 & 7.25 & 14.5 & 29.0 & 43.5 & 72.5 & 108.8 \\
\hline $\mathrm{TMZ}_{0.026}-\mathrm{MOR}(\mu \mathrm{M} \mathrm{TMZ})$ & 245.0 & 6.15 & 12.3 & 24.5 & 49.0 & 73.0 & 123.0 & 192.0 \\
\hline
\end{tabular}

MTIC and $m / z$ 126.05358 $\left[\mathrm{M}^{+}\right.$calcd 126.05361 for $\left.\mathrm{C}_{4} \mathrm{H}_{6} \mathrm{ON}_{4}\right]$ attributed to AIC. The HRMS analysis confirms the presence of different fragments from the cleavage of the TMZ molecule described in Fig. 1. These results show that the preparation method used preserved the integrity of TMZ into the zeolites but when its release occurs from DDS in the simulated body fluid at pH 7.4 and $37^{\circ} \mathrm{C}$, the hydrolysis of the molecule was achieved.

\section{Drug bioactivity studies}

The drug bioactivity studies were carried out in U251 glioblastoma cell line. This cell line was chosen as predictive model to test the potentiation of the chemotherapeutic agent TMZ into the zeolites NaY and NaMOR. The alterations in cell growth were noticed after $72 \mathrm{~h}$ of incubation with DDS and the parent zeolites.

Firstly, we tested a wide range of DDS concentrations and found that above $0.75 \mathrm{mg} \mathrm{mL}{ }^{-1}$ there is high rate of cell dead, probably because from this concentration the cells are completely coated by the zeolite, which compromise the cellnutrient exchange with the culture media (Fig. 4). ${ }^{25}$ Thus, the following assays were performed by preparing several working DDS concentrations, by making first a stock suspension $(1.0 \mathrm{mg}$ $\mathrm{mL}^{-1}$ ) in culture medium and then sequential dilutions from this stock. The concentrations of zeolite suspensions used in the present work and the corresponding TMZ final concentrations are presented in Table 1.

To determine the cytotoxic effect of the DDS in U251 cell line, two different viability tests were used, the MTS and the trypan blue assays (Fig. 5 and 6). Regarding $\mathrm{TMZ}_{0.015}-\mathrm{Y}$ results, in the MTS assay the parent zeolite induces more than $50 \%$ reduction in cell viability from dose $0.2 \mathrm{mg} \mathrm{mL} \mathrm{mL}^{-1}$ (Fig. 5), which is different from what we had found for colon cancer cell lines, ${ }^{28}$ where this zeolite had no cytotoxicity. However, due to its high cytotoxicity in glioblastoma cells, we have no additional effect in the DDS prepared with NaY (Fig. 5), which lead to conclude that this is not a good system for TMZ delivery in those cancer cells. Probably the acidity of the zeolite is important for this cell line. The results suggest that the lower $\mathrm{Si} / \mathrm{Al}$ ratio of NaY zeolite induces toxicity in all range of the concentrations studied. Our results confirm that the toxicity studies are dependent of the cell type and physicochemical properties of the zeolite structure. ${ }^{30}$

Concerning the tests with NaMOR zeolite in presence of the two different methods, this structure has only a mild cytotoxic effect for U251 cell line at a dose of $0.75 \mathrm{mg} \mathrm{mL}^{-1}$ (Fig. 6a and b), indicating the best DDS prepared in this study for drug delivery in glioblastoma. In the MTS assay (Fig. 6a) above $0.1 \mathrm{mg}$ $\mathrm{mL}^{-1}$ of $\mathrm{TMZ}_{0.026}-\mathrm{MOR}$ there was a significant reduction in

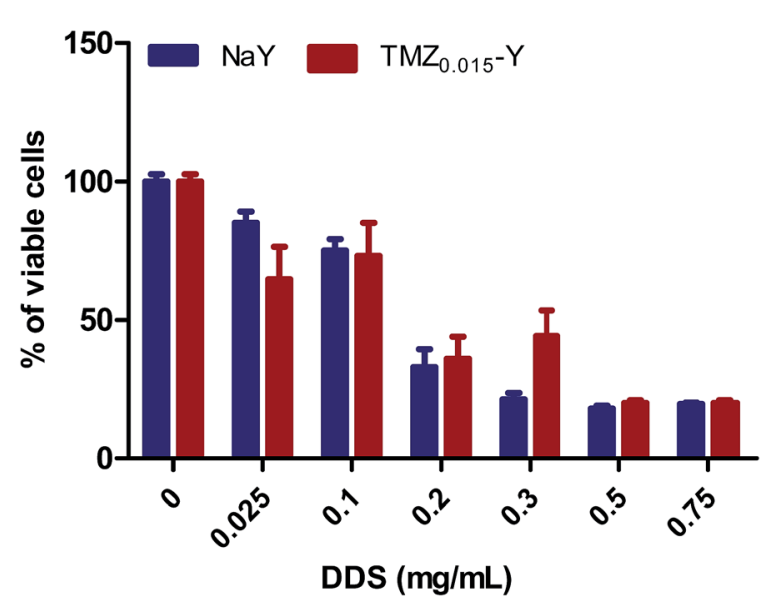

Fig. 5 Cell viability of U251 cells was measured by MTS assay after cell incubation with increasing concentrations of DDS ( $T M Z_{0.015}-\mathrm{Y}$ or $\mathrm{NaY}$ ) for $72 \mathrm{~h}$. The results are expressed in relation to the control $\left(0 \mathrm{mg} \mathrm{mL}^{-1}\right.$ of DDS, considered as $100 \%$ of viability) as the mean percentage \pm SD of viability. 
(a)

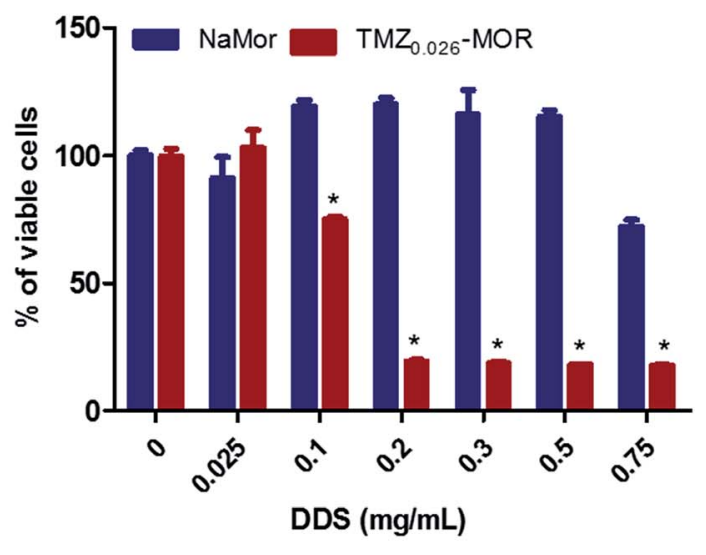

(c)

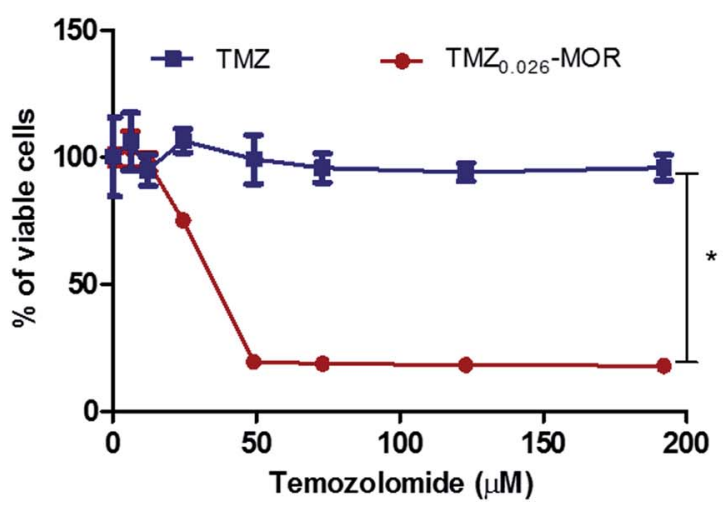

(b)

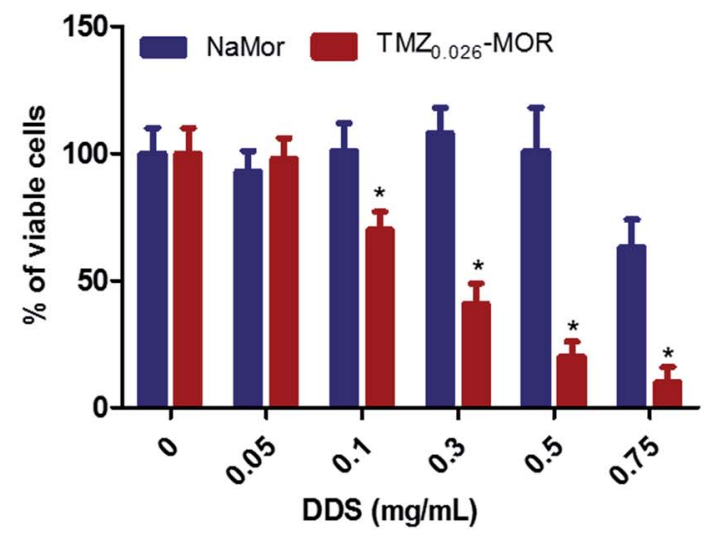

(d)

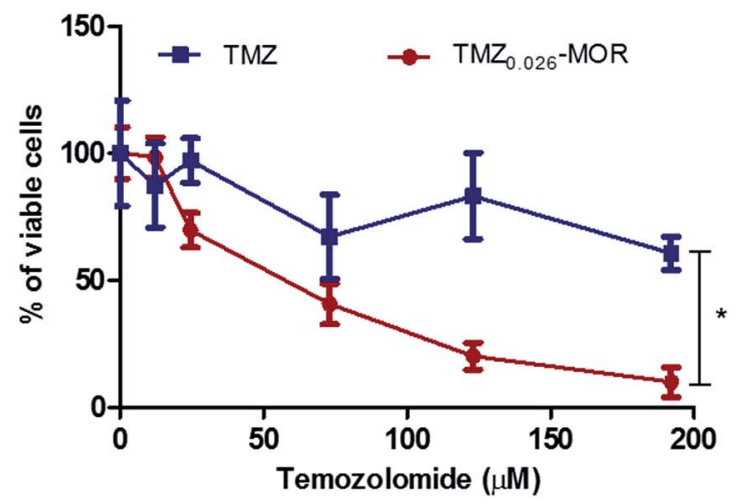

Fig. 6 Cell viability of U251 cells was measured after cell incubation with increasing concentrations of DDS (TMZ $0.026-M O R$ or NaMOR alone)

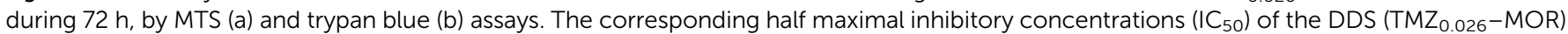
and TMZ free were calculated by MTS (c) and trypan blue (d) assays. All the results presented are expressed in relation to the control $(0 \mu M$ of TMZ, considered as $100 \%$ of viability) as the mean percentage \pm SD of viability. Differences with a $p<0.05$ were considered statistically significant (*).

cellular viability by comparison with the parent zeolite. In contrast, for the corresponding TMZ concentrations (Table 1), when administrated free, this drug has no effect on cell death (Fig. 6c). The MTS assay evaluates the metabolic activity of the cells and, to exclude the possibility of a metabolic change due to the low oxygenation of the cells incubated with the zeolites, which could turn the cells more sensitive to TMZ. In order to validate the MTS results, the trypan blue assay was done by counting the viable cells after trypan blue staining. By this method a significant dose dependent decrease in cell viability in the presence of $\mathrm{TMZ}_{0.026}-\mathrm{MOR}$ in comparison with the parent zeolite was observed (Fig. 6b). Nevertheless, the same trend was not observed for MTS assay (Fig. 6a).

To validate our findings, we run the same experiment in SNB19 cell line, where we found that for these cells the NaMor presents some cytotoxicity by MTS assay, indicating that the cytotoxicity of those zeolites seems to be cell line dependent, as discussed above. ${ }^{28}$

However, a potentiation of the TMZ effect was found with a significant reduction in cellular viability by comparison with the parent zeolite alone (Fig. 7a) in a way that is not dose dependent, similar to what was found for U251 cell line (Fig. 6a).

To determine whether the DDS is more efficient than the free temozolomide, the $\mathrm{IC}_{50}$ values before and after TMZ loading into the zeolite were calculated. The $\mathrm{IC}_{50}$ for the free temozolomide was difficult to calculate with both viability methods (MTS and trypan blue) since for the higher dose used $(192 \mu \mathrm{M}$, corresponding to $0.75 \mathrm{mg} \mathrm{mL}{ }^{-1}$ of $\left.\mathrm{TMZ}_{0.026}-\mathrm{MOR}\right)$ there is still more than $50 \%$ of cellular viability (Fig. $6 \mathrm{c}$, $\mathrm{d}$ and $7 \mathrm{~b}$ ). In contrast, after loading of TMZ on the NaMOR zeolite the new $\mathrm{IC}_{50}$ values for this compound in U251 cell lines were of 36.6 and $51.9 \mu \mathrm{M}$ for MTS and trypan blue assays, respectively. For SNB-19 cell line, after loading TMZ in the NaMOR zeolite reach an $\mathrm{IC}_{50}$ of $150 \mu \mathrm{M}$ (Fig. 7b).

By comparing the results obtained when treating cells with the free TMZ taking in account the value $192 \mu \mathrm{M}$ and the $\mathrm{TMZ}_{0.026}-\mathrm{MOR}$, there is an obvious potentiation of the effect of the drug. There is approximately an increase in efficiency of the drug between 5.2 and 3.7-fold, corresponding to MTS and trypan blue assays, respectively. For this zeolite, we used also the loading with $2.9 \mathrm{mg}$ of $\mathrm{TMZ}$ ( $\left.\mathrm{TMZ}_{0.015}-\mathrm{MOR}\right)$, however by comparison with the parent zeolite the DDS with TMZ loading had no additional cytotoxic effects (data not shown).

Previous results from our group with U251 cell line, ${ }^{36,37}$ have shown that in fact the $\mathrm{IC}_{50}$ for temozolomide can be dependent on the cell viability method used. We have determined an $\mathrm{IC}_{50}$ of $500 \mu \mathrm{M}$ using MTS $^{36}$ and $150 \mu \mathrm{M}$ using sulforhodamine B assay (SRB) ${ }^{37}$ for $\mathrm{U} 251$ cells, and of $955 \mu \mathrm{M}$ using MTS $^{36}$ for SNB- 
(a)

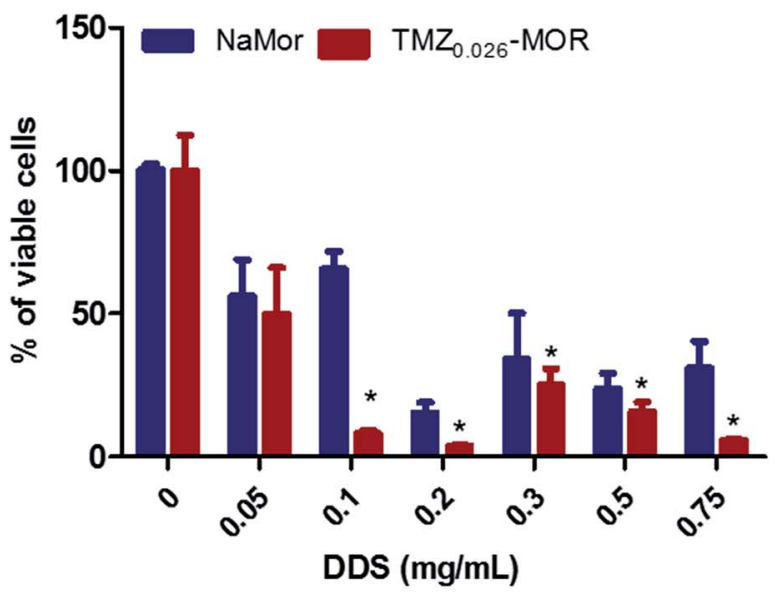

(b)

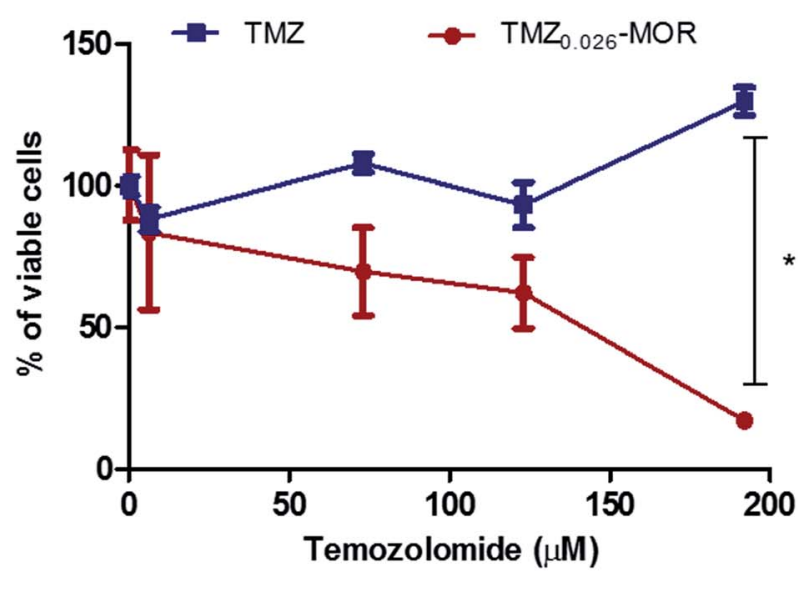

Fig. 7 Cell viability of SNB-19 cells was measured after cell incubation with increasing concentrations of DDS (TMZ $0.026-M O R$ or NaMOR alone) or TMZ free during $72 \mathrm{~h}$. The corresponding half maximal inhibitory concentrations $\left(\mathrm{IC}_{50}\right)$ of the DDS $\left(T M Z_{0.026}-M O R\right)$ and TMZ free were calculated by MTS assay. All the results presented are expressed in relation to the control ( $0 \mu \mathrm{M}$ of TMZ, considered as $100 \%$ of viability) as the mean percentage \pm SD of viability. Differences with a $p<0.05$ were considered statistically significant $(*)$.

19 cells. Even so, using TMZ loading in NaMOR zeolite we reached $\mathrm{IC}_{50}$ values that are at least 3 times lower than for free TMZ in both cell lines in the present study.

The CAM assay, an in vivo model, was performed to test the viability of the DDS in an in vivo microenvironment, using U251 cells. This model allows a 3D tumor formation that is important in the context of tumor microenvironment and cellular metabolism, which is similar to a real tumor than $2 \mathrm{D}$ cancer cell cultures (Fig. 8). ${ }^{36,37}$ U251 cell microtumors were grown in the CAM for 12 days, and treatment with DDS was initiated. As it can be observed, both the controls and the tumours treated with the parent NaMor zeolite continue to grow over time, while a clear regression of tumour mass was observed in the tumours treated with the DDS loaded with TMZ (Fig. 8). These studies show that TMZ loaded in NaMor zeolite was able to reduce tumour size in vivo. (a)

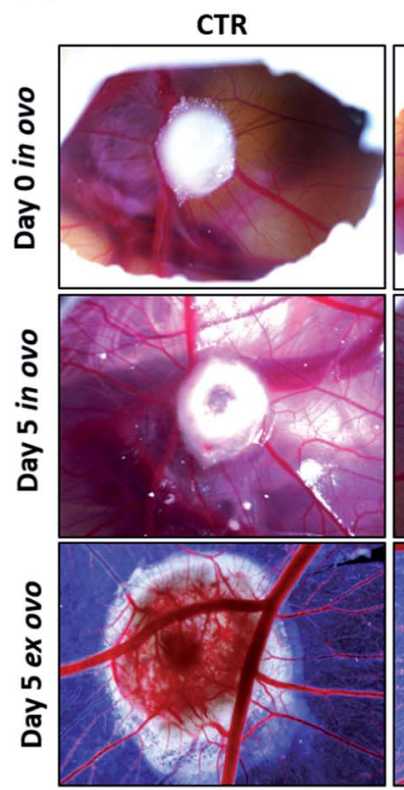

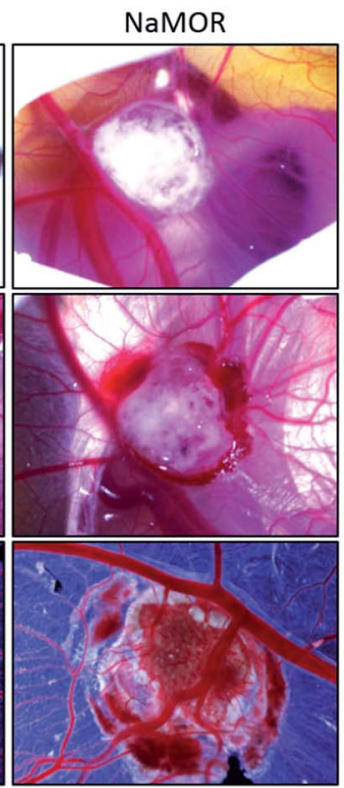

(b)

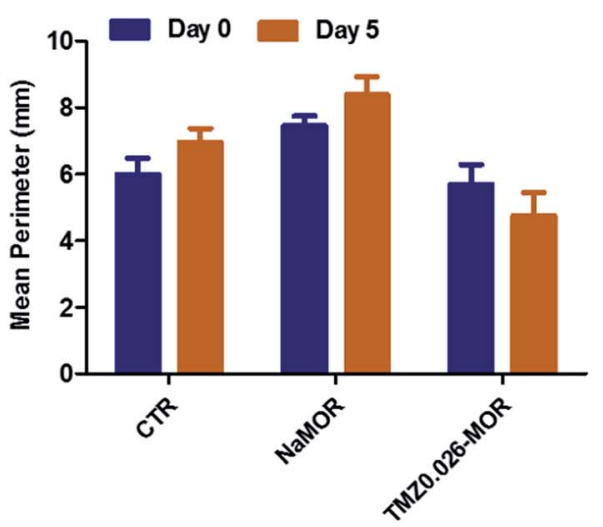

Fig. 8 In vivo effect of DDS in U251 glioblastoma cell line growth and angiogenesis. (a) Representative pictures of CAM assay in ovo (10x magnification) and ex ovo (16× magnification) at days 12 and 17 of development. (b) Tumor growth was measured as described in materials and methods. The results were expressed as mean perimeter \pm SD of tumors in the day 0 of treatment (12 days of development) until day 5 of treatment with DDS (17 days of development). A total of 9 eggs were used for tumor formation ( 3 were untreated, 3 were treated with $0.75 \mathrm{mg}$ $\mathrm{mL}^{-1}$ of $\mathrm{TMZ}_{0.026}-\mathrm{MOR}$ and 3 with $0.75 \mathrm{mg} \mathrm{mL}^{-1}$ of NaMOR zeolite). 


\section{Conclusions}

The conventional treatment of cancer by chemotherapy was widely used in clinical while the side-effects were very severe. Recently the development of new drug delivery systems which could reduce systemic circulation of the drug leading to higher therapeutic efficacy and lower systemic toxicity has been carried out. The results from this work demonstrated that zeolite structures can be used effectively for sustained release applications in glioblastoma cells. Zeolites Y and MOR were used as hosts for the anticancer drug temozolomide. These zeolitic structures were selected because their combination of $\mathrm{Si} / \mathrm{Al}$ ratio, wide and accessible pore was expected to be favorable for enhances the potentiation of TMZ. Besides, these structures preserve the integrity of TMZ without their conversion in MTIC before the contact with the cells. Only the mordonite structure with 1D framework presented no cytotoxic effects in the cells. TMZ loaded in this structure can be at least three times more effective in cell death induction than free TMZ administered both in vitro and in vivo. Further studies are needed to extend these findings and evaluated other biological impacts of mordonite-load TMZ, in order to become a more effective therapy for glioblastoma patients.

\section{Acknowledgements}

R.A. and N.V. are recipients of PhD fellowships (SFRH/BI/51118/ 2010 and SFRH/BD/97797/2013) from Fundação para a Ciência e a Tecnologia (FCT, Portugal). O.M. is a recipient of a Post-Doc fellowship (UMINHO/BPD/32/2013) from QREN. The authors thank the FCT and FEDER-COMPETE-QREN-EU for financial support to the Research Centers, CQ/UM, PEst-C/QUI/UI0686/ 2013 (F-COMP-01-0124-FEDER-037302) and Life and Health Sciences Research Institute (ICVS, University of Minho, Portugal). The NMR spectrometer is part of the National NMR Network (RNRMN), supported with funds from FCT/QREN (Quadro de Referência Estratégico Nacional).

\section{Notes and references}

1 D. N. Louis, H. Ohgaki, O. D. Wiestler, W. K. Cavenee, P. C. Burger, A. Jouvet, B. W. Scheithauer and P. Kleihues, Acta Neuropathol., 2007, 114, 97-109.

2 S. Tanaka, D. N. Louis, W. T. Curry, T. T. Batchelor and J. Dietrich, Nat. Rev. Clin. Oncol., 2013, 10, 14-26.

3 M. Weller, M. van den Bent, K. Hopkins, J. C. Tonn, R. Stupp, A. Falini, E. Cohen-Jonathan-Moyal, D. Frappaz, R. Henriksson, C. Balana, O. Chinot, Z. Ram, G. Reifenberger, R. Soffietti and W. Wick, European Association for Neuro-Oncology (EANO) Task Force on Malignant Glioma, Lancet Oncol., 2014, 15, 395-403.

4 R. Stupp, M. J. van den Bent and M. E. Hegi, Curr. Neurol. Neurosci. Rep., 2005, 5, 198-206.

5 R. Stupp, W. P. Mason, M. J. van den Bent, M. Weller, B. Fisher, M. J. Taphoorn, K. Belanger, A. A. Brandes, C. Marosi, U. Bogdahn, J. Curschmann, R. C. Janzer, S. K. Ludwin, T. Gorlia, A. Allgeier, D. Lacombe,
J. G. Cairncross, E. Eisenhauer and R. O. Mirimanoff, European Organisation for Research and Treatment of Cancer Brain Tumor and Radiotherapy Groups; National Cancer Institute of Canada Clinical Trials Group, N. Engl. J. Med., 2005, 352, 987-996.

6 H. S. Friedman, T. Kerby and H. Calvert, Clin. Cancer Res., 2000, 6, 2585-2597.

7 M. J. M. Darkes, G. L. Plosker and B. Jarvis, Am. J. Cancer, 2002, 1, 55-80.

8 S. J. Danson and M. R. Middleton, Expert Rev. Anticancer Ther., 2001, 1, 13-19.

9 C. K. Augustine, J. S. Yoo, A. Potti, Y. Yoshimoto, P. A. Zipfel, H. S. Friedman, J. R. Nevins, F. Ali-Osman and D. S. Tyler, Clin. Cancer Res., 2009, 15, 502-510.

10 B. M. Costa, C. Caeiro, I. Guimarães, O. Martinho, T. Jaraquemada, I. Augusto, L. Castro, L. Osório, P. Linhares, M. Honavar, M. Resende, F. Braga, A. Silva, F. Pardal, J. Amorim, R. Nabiço, R. Almeida, C. Alegria, M. Pires, C. Pinheiro, E. Carvalho, J. M. Lopes, P. Costa, M. Damasceno and R. M. Reis, Oncol. Rep., 2010, 23, 16551662.

11 N. Gaspar, L. Marshall, L. Perryman, D. A. Bax, S. E. Little, M. Viana-Pereira, S. Y. Sharp, G. Vassal, A. D. Pearson, R. M. Reis, D. Hargrave, P. Workman and C. Jones, Cancer Res., 2010, 70, 9243-9252.

12 M. J. Riemenschneider, M. E. Hegi and G. Reifenberger, Targeted Oncol, 2010, 5, 161-165.

13 M. Weller, R. Stupp, G. Reifenberger, A. A. Brandes, M. J. van den Bent, W. Wick and M. E. Hegi, Nat. Rev. Neurol., 2010, 6, 39-51.

14 M. E. Hegi, A. C. Diserens, T. Gorlia, M. F. Hamou, N. de Tribolet, M. Weller, J. M. Kros, J. A. Hainfellner, W. Mason, L. Mariani, J. E. Bromberg, P. Hau, R. O. Mirimanoff, J. G. Cairncross, R. C. Janzer and R. Stupp, N. Engl. J. Med., 2005, 352, 997-1003.

15 J. Arrowsmith, S. A. Jennings, A. S. Clark and M. F. Stevens, J. Med. Chem., 2002, 45, 5458-5470.

16 A. W. White, R. Almassy, A. H. Calvert, N. J. Curtin, R. J. Griffin, Z. Hostomsky, K. Maegley, D. R. Newell, S. Srinivasan and B. T. Golding, J. Med. Chem., 2000, 43, 4084-4097.

17 T. López, J. Sotelo, J. Navarrete and J. A. Ascencio, Opt. Mater., 2006, 29, 88-94.

18 A. W. Scott, B. M. Tyler, B. C. Masi, U. M. Upadhyay, Y. R. Patta, R. Grossman, L. Basaldella, R. S. Langer, H. Brem and M. J. Cima, Biomaterials, 2011, 32, 2532-2539.

19 B. C. Masi, B. M. Tyler, H. Bow, R. T. Wicks, Y. Xue, H. Brem, R. Langer and M. J. Cima, Biomaterials, 2012, 33, 5768-5775. 20 G. Huang, N. Zhang, X. Bi and M. Dou, Int. J. Pharm., 2008, 355, 314-320.

21 J. Li, Y. Wang, Y. Zhu and D. Oupický, J. Controlled Release, 2013, 172, 589-600.

22 M. Danilczuk, K. Długopolska, T. Ruman and D. Pogocki, Mini-Rev. Med. Chem., 2008, 8, 1407-1417.

23 D. G. Fatouros, D. Douroumis, V. Nikolakis, S. Ntais, A. M. Moschovi, V. Trivedi, B. Khima, M. Roldo, H. Nazar and P. A. Cox, J. Mater. Chem., 2011, 21, 7789-7794. 
24 N. Vilaça, R. Amorim, O. Martinho, R. M. Reis, F. Baltazar, A. M. Fonseca and I. C. Neves, J. Mater. Sci., 2011, 46, 7511-7516.

25 N. Vilaça, R. Amorim, A. F. Machado, P. Parpot, M. F. R. Pereira, M. Sardo, J. Rocha, A. M. Fonseca, I. C. Neves and F. Baltazar, Colloids Surf., B, 2013, 112, 237-244.

26 M. Spanakis, N. Bouropoulos, D. Theodoropoulos, L. Sygellou, S. Ewart, A. M. Moschovi, A. Siokou, I. Niopas, K. Kachrimanis, V. Nikolakis, P. A. Cox, I. S. Vizirianakis and D. G. Fatouros, Nanomed-Nanotechnol, 2014, 10, 197205.

27 A. Corma and H. Garcia, Eur. J. Inorg. Chem., 2004, 11431164.

28 R. Amorim, N. Vilaça, O. Martinho, R. M. Reis, M. Sardo, J. Rocha, A. M. Fonseca, F. Baltazar and I. C. Neves, J. Phys. Chem. C, 2012, 116, 25642-25650.

29 I. Fenoglio, A. Croce, F. Di Renzo, R. Tiozzo and B. Fubini, Chem. Res. Toxicol., 2000, 13, 489-500.

30 A. Petushkov, N. Ndiege, A. K. Salem and S. C. Larsen, Toxicity of Silica Nanomaterials: Zeolites, Mesoporous Silica, and Amorphous Silica Nanoparticles, in Advances in Molecular Toxicology, ed. James C. Fishbein, Elsevier, 2010, vol. 4, p. 223.
31 H. Figueiredo, B. Silva, C. Quintelas and I. C. Neves, Chem. Eng. J., 2010, 163, 22-27.

32 I. Kuźniarska-Biernacka, K. Biernacki, A. L. Magalhães, A. M. Fonseca and I. C. Neves, J. Catal., 2011, 278, 102-110.

33 I. C. Neves, C. Cunha, M. R. Pereira, M. F. R. Pereira and A. M. Fonseca, J. Phys. Chem. C, 2010, 114, 10719-10724.

34 A. Datt, D. Fields and S. C. Larsen, J. Phys. Chem. C, 2012, 116, 21382-21390.

35 Database of Zeolite Structures from the International Zeolite Association,http://www.iza-structure.org/databases/, acessed in 05 september 2014.

36 O. Martinho, R. Silva-Oliveira, V. Miranda-Gonçalves, C. Clara, J. R. Almeida, A. L. Carvalho, J. T. Barata and R. M. Reis, Transl. Oncol., 2013, 6, 187-196.

37 V. Miranda-Gonçalves, M. Honavar, C. Pinheiro, O. Martinho, M. M. Pires, C. Pinheiro, M. Cordeiro, G. Bebiano, P. Costa, I. Palmeirim, R. M. Reis and F. Baltazar, Neuro-Oncology, 2013, 15, 172-188.

38 B. J. Denny, R. T. Wheelhouse, M. F. Stevens, L. L. Tsang and J. A. Slack, Biochemistry, 1994, 33, 9045-9051.

39 N. J. Babu, P. Sanphui and A. Nangia, Chem.-Asian J., 2012, 7, 2274-2285.

40 M. A. Camblor, A. Corma and S. Valencia, Microporous Mesoporous Mater., 1998, 25, 59-74. 